\title{
Mineral supplement with pre- and probiotic improves respiratory immune status in yearling racing Thoroughbred horses: preliminary results
}

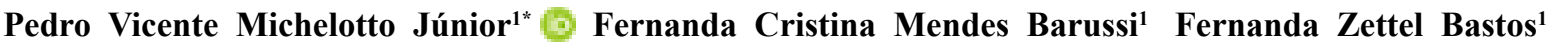 Ana Lúcia Lacerda Michelotto ${ }^{1}$ Saulo Henrique Weber ${ }^{1}$}

${ }^{1}$ Programa de Pós-graduação em Ciência Animal, Escola de Ciências da Vida, Pontifícia Universidade Católica do Paraná (PUCPR), Rua Imaculada Conceição, 1155, 80215-901, Curitiba, PR, Brasil. E-mail: p.michelotto@pucpr.br. "Corresponding author.

\begin{abstract}
There are evidences of intestinal flora influence on the airway immune response. However, this information is scarce with regard to horses. The present preliminary study aimed to investigate the effects of a commercial mineral supplement containing probiotics and prebiotics on the respiratory immune response of horses supplemented with them during the first months of stabling and race training. Twelve TB yearlings were examined at the breeding farm at the beginning of the study (June 2016, henceforth M0) and then reexamined one (July 2016, henceforth M1) and five (November 2016, henceforth M2) months after being stabled at a racetrack in Curitiba, Brazil. Clinical and hematological examinations, airway endoscopy, and tracheal wash (TW) cytology were performed. After the initial examination, horses were randomly divided between the treatment group (TG), which received 10 grams of the supplement daily, and the control group (CG). There was no difference between the groups in terms of clinical parameters; in the hematological examination, eosinophil count was lower in the TG in $M 1$ as compared with M0 $(P=0.045)$. Pharyngeal lymphoid hyperplasia $(P L H)$ improved in the TG during M1 as compared with M0 ( $P=$ 0.007). However, on the CG, PLH remained unchanged. Relative number of eosinophils in the TW was $86.1 \%$ higher in M1 than M0 for the $C G$; in the TG; however, eosinophils were absent and remained within normal limits until M2. In conclusion, this study revealed a positive influence of probiotic and prebiotic supplementation on the respiratory immune response of young TB race horses. Further investigations are recommended.
\end{abstract}

Key words: airway inflammation, endoscopy, intestinal flora, prebiotic, probiotic.

Suplemento mineral com pre- e probiótico melhora a condição imunológica respiratória em cavalos sobreano Puro Sangue Inglês de corrida: resultados preliminares

RESUMO: As doenças respiratórias são uma grande preocupação em cavalos Puro Sangue Inglês (PSI) jovens durante o primeiro ano de treinamento para corrida. Existem evidências da influência da flora intestinal sobre a condição imunológica do organismo, incluindo a resposta de defesa das vias aéreas, porém essas informações são escassas nos cavalos. O presente estudo preliminar teve como objetivo investigar a influência da suplementação com núcleo mineral comercial com probiótico e prebiótico sobre a resposta imunológica respiratória de cavalos PSI durante os primeiros meses de estabulagem e treinamento. Doze cavalos PSI na fase de sobreano, machos e fêmeas, foram examinados ainda no haras (M0) e, um mês (M1) e cinco meses (M5) após estabulação no hipódromo em Curitiba, Brasil. Os cavalos foram submetidos a exames clínico e hematológico, endoscopia das vias aéreas e citologia do lavado traqueal (LT). Após o primeiro exame, os cavalos foram divididos aleatoriamente em grupo tratado (GT), que recebeu $10 \mathrm{~g}$ por dia do suplemento, e grupo de controle (GC). Não houve diferença nos parâmetros clínicos, já no exame hematológico do GT, a contagem de eosinófilos foi menor em M1 quando comparado a M0 (P = 0,045). A hiperplasia folicular linfoide ficou dentro do limite normal e menores no GT em M1 quando comparado a M0 (P =0.007), o que não ocorreu para o GC. O número relativo de eosinófilos no LT foi 86,1\% maior em M1 versus M0 para o GC, enquanto no GT, os eosinófilos estavam ausentes e permaneceram dentro dos limites normais até M2. Concluindo, neste estudo preliminar, evidenciou-se uma influência positiva da suplementação probiótica e prebiótica na resposta imunológica respiratória de cavalos PSI jovens, justificando investigações adicionais. Palavras-chave: endoscopia, flora intestinal, inflamação das vias aéreas, prebiótico, probiótico.

Airway diseases are the major cause of poor performance in race horses, being the second most prevalent condition affecting the two-yearold Thoroughbreds (TB)(WILSHER et al., 2006). Relationship amongst stabling, feeding hay, and respiratory diseases is well understood. It is known that stabled horses are exposed to high levels of organic dust; this instigates inflammatory processes in the airways (HOLCOMBE et al., 2001).

Some studies with young TB horses beginning race training investigated the importance of the transition from the field to the barn 
environment for the athletic horse's respiratory health. Airway eosinophilia was observed in the first month of stabling (IVESTER et al., 2014), as well as anincreased phagocytic activity of the alveolar macrophages, and production of oxygen and nitrogen reactive species (MICHELOTTO Jr. et al., 2010). Neutrophilic inflammation was observed during the second month of stabling, while eosinophilic inflammation was noted during the third month of stabling (ALMEIDA, 2015). All of these are probably responses to the new environment.

The intestinal microbiota is considered to influence the airway response to an inflammatory insult, as it plays a role in the development of allergic asthma (PANZER \& LYNCH, 2015). Furthermore, colonization of good bacteria in the intestinal flora of $\mathrm{Balb} / \mathrm{C}$ mice during their early life was able to prevent airway inflammation in asthma by regulation the Th1/Th2 balance (QIAN et al., 2017). Thus, the term probiotic emerges as living microorganisms that may benefit the host (PANDEY et al., 2015). Next to it appears the term prebiotic, which represents non-digestible food that contributes to the development of host microorganisms (DE VRESE \& SCHREZENMEIR, 2008).

Airway inflammation can affect up to $80 \%$ of the young TB racehorses during their first year of race training (CHRISTLEY \& RUSH, 2007), but studies about the relationship between airway inflammation and young TB gut environment are scarce. In this context, the present study raised the hypothesis that improving intestinal flora quality of the yearling TB horses prior to training could positively influence their airway condition during the initial months of race training. Furthermore, the aim of the present study was to test whether supplementation with a commercial mineral nucleus with probiotic and prebiotics (MNPP) would influence the airway response of young TB race horses prior to training.

Twelve TB race horses from the same owner, seven male and five female, with a mean age of $21 \pm 1.1$ months at the beginning of the study, were examined from June through November 2016. At the beginning of the study, all the animals were at the farm in the region of São José dos Pinhais, around $30 \mathrm{~km}$ from the racetrack in the city of Curitiba, Paraná state, south of Brazil. Horses were vaccinated against Equine Influenza, Herpesvirus 1 and 4, and tetanus, and dewormed accordingly to the farm program.

The 12 horses were initially examined at the farm in June 2016 (M0) (autumn), with clinical examination (cardiac and respiratory rate, mucous membranes, arterial pulse, tracheal and pulmonary auscultation, rectal temperature), hematological analysis of blood collected from the jugular vein. Upper and lower airway endoscopy and cytological examination of the tracheal wash (TW) were performed.

The airway endoscopic examination evaluated pharyngeal lymphoid hyperplasia (PLH), which was graded 1-4 (RAKER \& BOWLES, 1978), and the amount of tracheal mucus (TM), which was graded 0-5 (GERBER et al., 2004). The TW was obtained while the endoscope was near the tracheal bifurcation by instilling $20 \mathrm{~mL}$ of sterile saline and then retrieving the saline immediately. The recovered TW fluid was transferred to centrifuge tubes and immediately centrifuged at $340 \mathrm{~g}$ for 6 minutes at room temperature. The formed cell pellets were used to make the slides for the cytological investigation, being colored with Romanowski stain (Panótico, Laborclin, Pinhais, PR, Brasil).This investigation involved counting 300 cells at 1000x magnification. The TW evidencing $<10 \%$ lymphocytes, $<1 \%$ eosinophils and $<20 \%$ neutrophils, were considered to be normal (HODGSON \& HODGSON, 2003).

After the first examination, the group of horses was randomly divided into a control group $(\mathrm{CG}, \mathrm{n}=6)$ and a treated group $(\mathrm{TG}, \mathrm{n}=6)$. The horses of the $\mathrm{CG}$ were transferred to the racetrack in the day after M0 and housed in individual barns of $3.0 \times 3.0 \mathrm{x}$ $3.0 \mathrm{~m}$ with sawdust beds. They received smashed oats and commercial feed plus alfalfa hay, and had free access to water. The horses of the TG remained at the farm, being part of the time housed, and part of the time at pasture. They began to receive a commercial MNPP (10g daily) containing Bifidobacterium bifidum, Enterococcus faecium, Lactobacillus casei, Pediococcus acidilactici, Saccharomyces cerevisiae, mycotoxin adsorbent, sulfur, manganese sulfate, zinc oxide, mannanoligosaccharides and glucans (Equusflora $^{\circledR}$, Kera Animal Nutrition, Farroupilha, Brazil), added to the top of the afternoon feed. After 30 more days at the farm, animals of the TG joined the rest of the group at the racetrack.

Horses of both groups were reexamined by the same protocol on initial examination after 30 days (M1) (July and August, winter) and 150 days (M2) (October and November, spring) of stabling at the racetrack.

Statistical analysis was performed using the Mann-Whitney test to compare each moment of examination between groups and also to compare each group's moments againstits M0. The data is presented as mean \pm standard error (SE) for the PLH and TM, and mean \pm standard deviation (SD) for the quantitative data. All the analyses were performed using the 
software GraphPad Prism 5.0 for Windows (San Diego, CA, USA), considering $\mathrm{P}<0.05$ as significant.

The clinical parameters did not change amongst the examined horses. There was no significant difference noted between the groups during the different moments of examination.

In the endoscopic examination, while the PLH grade was unchanged for the CG $(2.0 \pm 0.6$ vs. $2.2 \pm 0.9, \mathrm{P}=1.0)$, it decreased significantly for horses in the TG during M1 in comparison with M0 $(1.5 \pm 0.2$ vs. $2.8 \pm 0.2, \mathrm{P}=0.007)$. PLH usually develop in the young horse as an immune reaction to inhaled particles from the new environment, and are expected to disappear by the age of six years due to the maturity of the immune system (HOBO et al., 1995). Interestingly, in a previous study of our group (ALMEIDA, 2015), PLH was significantly reduced just one year after stabling, in comparison with the preliminary examinations. The current study suggested a positive influence of the commercial MNPP on the pharyngeal immune system, resulting in a better adaptation of the pharyngeal lymphoid tissue to the new environment by reducing the inflammatory reaction on the airways, thereby protecting it.

Even though the groups were randomized, the TG had a higher TM grade than the CG in M0 $(2.3 \pm 0.6$ vs. $0.3 \pm 0.2, \mathrm{P}=0.009)$. The TM of the TG did not evidence significant modifications in M1 $(1.5 \pm 0.4, \mathrm{P}=0.25)$ and in $\mathrm{M} 2(3.3 \pm 0.4, \mathrm{P}=0.25)$. As for the CG, the TM increased in M1 $(2.2 \pm 0.9$, P $=0.07)$ and significantly increased in $\mathrm{M} 2(3.0 \pm 0.5$, $\mathrm{P}=0.007)$. Tracheal mucus is considered part of the lower airways' protection as particles become trapped in it and are driven towards the pharynx. However, increased amounts of tracheal mucus are considered a clinical sign of airway inflammation. For the racehorses, it has been noted that a TM grade of 2 or higher interferes with the pulmonary function of gas exchange (HOLCOMBE et al., 2006). As the amount of TM did not increase for the TG, it was considered an important finding because it corroborated with the lower grade of PLH in this group during M1.

In the hematologic examination, there was no difference in the total leukocyte and erythrocyte counts between groups and among different moments. Eosinophil count decreased in the horses of the TG in the M1 examination as compared with M0 (0.83 \pm 0.75 vs. $1.5 \pm 0.71$ cells $/ \mathrm{ml}, \mathrm{P}=0.045$ ).

In relation to the relative number of eosinophils reported in the TW, there was an increase of $86.1 \%$ in CG during M1 when compared with M0 $(1.2 \pm 1.8 \%$ vs. $0.17 \pm 0.4 \%)$, and it was higher than the normal upper limit. However, the increase was not significant. There were no eosinophils in the TW of the TG in M1. In M2 the eosinophils were within normal limits. Dust particles of new environments could be expected to induce eosinophilic and mastocytic airway inflammation. These changes could signify adaptations (ALMEIDA, 2015). Although, these are temporary in most cases, this phase can evolve to become an inflammatory process that affects the respiratory system and its future responses to new agents (IVESTER et al., 2014).

Regarding TW cytology, there was an increase in the relative number of macrophages in the CG in M2 $(68.7 \pm 16.4 \%$ vs. $41.7 \pm 13.1 \%, \mathrm{P}=$ $0.015)$ when compared with M0. In contrast, in the $\mathrm{TG}$, there was a slight reduction of macrophages by $22.5 \%$ in M1 with no further changes for M2 $(60.0$ $\pm 12.6 \%, 47.8 \pm 20.6 \%$ and $46.5 \pm 17.6 \%$, for $\mathrm{M} 0$, M1 and M2, respectively). Alveolar macrophages are the most prevalent cells of the innate immune defense system of the airways (GEISER, 2010), and are significantly active after 30 days of stabling prior to race training (MICHELOTTO Jr. et al., 2010). Further studies to identify the macrophage phenotype are recommended, especially to establish whether the increase in the number of macrophages in the $\mathrm{CG}$ means an increase in active cells. Another avenue of study is to identify the effect of symbiotic products those with probiotic and prebiotic - with regard to the immunomodulation of the airway immune response.

The neutrophils increased in M1 and M2 for both groups, but not significantly. Neutrophils were higher than the upper limit of normal values only for the TG in M1 $(22.0 \pm 22.7 \%)$ and M2 (23.8 $\pm 31.1 \%$ ). There were some fluctuations between the neutrophil values reported in both groups and among the periodic evaluations, where an animal presenting increased neutrophils in one evaluation was within the limit in the previous evaluation and in the subsequent evaluation. This showed that the increase in the number of neutrophils was transitory in each animal, and thus could also be part of the adaptation of the horses to the new physical requirements and the new environment, probably due to a higher concentration of endotoxins inside barns in comparison with pasture (BERNDT et al., 2008). In a similar population, ALMEIDA (2015) showed that there was an increase in neutrophils after 60 days of stabling, but a decrease in the following months.

In our study, beneficial effects of MNPP administration were noted, as the horses of the TG had the immune condition improved previously to being moved to the new environment at the racetrack. Positive effects on the airway immune response, 
specifically during the initial month of stabling, such as improvement in the grade of PLH, maintenance of TM grade, and a decrease in eosinophilic response, were observed. Further studies on the adaptive immune response in TB horses are recommended.

\section{ACKNOWLEDGEMENTS} participated in the study.

\section{BIOETHICS AND BIOSSECURITY COMMITTEE APPROVAL}

The present study was approved by the Ethics Committee on the Animal Use of the Pontifícia Universidade Católica do Paraná (PUCPR) (number 01044).

\section{DECLARATION OF CONFLICT OF INTERESTS}

The supplement was acquired from Kera Nutrição Animal. Authors were not under the employment of the supplement company. No financial resources were received from Kera Nutrição Animal for this study and no problems with patent were noted.

\section{REFERENCES}

ALMEIDA, S.R.P. Avaliação das vias aéreas de cavalos Puro Sangue Inglês estabulados, durante o primeiro ano de treinamento para corrida. 2015. 74f. Dissertação (Mestrado em Ciência Animal) - Curso de Pós-graduação em Ciência Animal, Pontifícia Universidade Católica do Paraná.

BERNDT, A. et al. Endotoxin concentrations within the breathing zone of horses are higher in stables than on pasture. The Veterinary Journal, v.183, p. 54-57, 2008. Available from: $<$ http://www.sciencedirect.com/ science/article/pii/S1090023308003158?via\%3Dihub>. Accessed: Oct. 30, 2017. doi: 10.1016/j.tvj1.2008.09.001.

CHRISTLEY, R.; RUSH, B.R. Inflammatory airway disease. In: MCGORUM, B.C.; DIXON, P.M.; ROBINSON, N.E.; SCHUMACHER, J. Equine Respiratory Medicine and Surgery, Philadelphia: Saunders Elsevier, 2007, p.591-599.

DEVRESE, M.; SCHREZENMEIR, J. Probiotics, prebiotics, and synbiotics. In: Food biotechnology. Springer Berlin Heidelberg, 2008. p. 1-66. Available from: <https://link.springer.com/ chapter/10.1007\%2F10_2008_097>.Accessed: Feb. 27, 2018. doi: 10.1007/10_2008_097.

GEISER,M. Update on macrophage clearance of inhaled microand nanoparticles. Journal of Aerosol Medicine and Pulmonary Drug Delivery, v.23, p.207-217, 2010. Available from: <https:// doi.org/10.1089/jamp.2009.0797>. Accessed: Oct. 30, 2017. doi: 10.1089/jamp.2009.0797.

GERBER, V. et al. Endoscopic scoring of mucus quantity and quality: observer and horse variance and relationship to inflammation, mucus viscoelasticity and volume. Equine Veterinary Journal, v.36, p.576-582, 2004. Available from:
$<$ https://www.ncbi.nlm.nih.gov/pubmed/15581321>. Accessed: Oct. 30, 2017. doi: 10.2746/0425164044864525.

HOBO, S. et al. Prevalence of upper respiratory tract disorders detected with a flexible videoendoscope in thoroughbred racehorses. Journal of Veterinary Medical Science, v.57, p.409-413, 1995. Available from: <https://www.ncbi.nlm.nih.gov/pubmed/7548390>. Accessed: Oct. 30, 2017.

HODGSON, J.L.; HODGSON, D.R. Tracheal aspirates: indications, technique, and interpretation. In: ROBINSON, N.E. Current Therapy in Equine Medicine, 5.ed. St. Louis: Saunders, 2003, p.401-407.

HOLCOMBE, S.J. et al. Stabling is associated with airway inflammation in young Arabian horses. Equine Veterinary Journal, v.33, n.3, p.244-249, 2001. Available from: <http://onlinelibrary. wiley.com/doi/10.2746/042516401776249606/abstract.>. Accessed: Oct. 30, 2017. doi: 10.2746/042516401776249606.

HOLCOMBE, S.J. et al. Effect of tracheal mucus and tracheal cytology on racing performance in Thoroughbred racehorses. Equine Veterinary Journal, v.38, p.300-304, 2006. Available from: <http://onlinelibrary.wiley.com/ doi/10.2746/042516406777749191/abstract.>. Accessed: Oct. 30, 2017. doi: $10.2746 / 042516406777749191$.

IVESTER, K.M.et al. Environmental exposures and airway inflammation in young thoroughbred horses. Journal of Veterinary Internal Medicine, v.28, p.918-924, 2014. Available from: <http:// onlinelibrary.wiley.com/doi/10.1111/jvim.12333/abstract. $>$. Accessed: Oct. 30, 2017. doi: 10.1111/jvim. 12333.

MICHELOTTO Jr., P.V. et al. Platelet-activating factor and evidence of oxidative stress in the bronchoalveolar fluid of Thoroughbred colts during race training. Journal of Veterinary Internal Medicine, v.24, p.414-419, 2010. Available from: $<$ http:// onlinelibrary.wiley.com/doi/10.1111/j.1939-1676.2010.0459.x/ abstract. $>$. Accessed: Oct. 30, 2017. doi: 10.1111/j.19391676.2010.0459.x.

QIAN, L.J. et al. Early-life gut microbial colonization shapes Th1/Th2 balance in asthma model in Balb/C mice. BMC Microbiology, v.17, p.135, 2017. Available from: <https://doi.org/10.1186/s12866-0171044-0. . Accessed: Oct. 30, 2017. doi: 10.1186/s12866-017-1044-0.

PANDEY, K. R.; NAIK, S. R.; VAKIL, B. V. Probiotics, prebiotics and synbiotics-a review. Journal of food science and technology, v. 52, n. 12 , p. $7577-7587,2015$. Available from: <https://link. springer.com/article/10.1007/s13197-015-1921-1>. Accessed: Feb. 27, 2018. doi: 10.1007/s13197-015-1921-1.

PANZER, A.R.; LYNCH, S.V. Influence and effect of the human microbiome in allergy and asthma. Current Opinion in Rheumatology, v.27, p.373-380, 2015. Available from: <https:// insights.ovid.com/pubmed?pmid=26002029. $>$. Accessed: Oct. 30, 2017. doi: 10.1097/BOR.0000000000000191.

RAKER, C.W.; BOLES, C.L. Pharyngeal lymphoid hyperplasia in the horse. Journal of Equine Medicine and Surgery, v.2, p.202-207, 1978.

WILSHER, S. et al. Factors associated with failure of thoroughbred horses to train and race. Equine Veterinary Journal, v.38, p.113118, 2006. Available from: <http://onlinelibrary.wiley.com/ doi/10.2746/042516406776563305/abstract.>. Accessed: Oct. 30, 2017. doi: 10.2746/042516406776563305. 